Received : 2020-04-30 Revised : 2020-06-08 Acceptance : 2021-04-28 Publish : 2021-06-17

\title{
ANALYSIS OF AGE, GENDER AND HEARING LOSS IN EARLY STAGE DRUG-RESISTANT TB PATIENTS AT ABDUL WAHAB SJAHRANIE HOSPITAL SAMARINDA
}

\author{
Rio Mandala Putra Ruslan ${ }^{1 *}$, Moriko Pratiningrum ${ }^{2}$, Eva Rachmi $^{3}$ \\ ${ }^{1}$ Medical Department, Faculty of Medicine, Mulawarman University \\ ${ }^{2}$ Poly Tulip, RSUD Abdul Wahab Syahranie Samarinda \\ *E-mail : rioruslan22@gmail.com
}

\begin{abstract}
Hearing loss is one of the side effects of using kanamycin. Hearing loss will reduce the ability to receive information and verbal communication which will interfere with daily activities. This study aims to determine the relationship between age, sex on hearing loss and hearing loss in patients with drugresistant TB during kanamycin treatment. The design of this study was cross sectional using purposive sampling. The number of samples that met the inclusion and exclusion criteria was 12 patients. The results show that hearing loss is not related to age $(\mathrm{p}=0.293)$, sex $(\mathrm{p}=1,000)$, and hearing loss $(\mathrm{p}=$ 0.182). Based on the results of this study it can be concluded that there is no relationship between age, sex on hearing loss and hearing loss during kanamycin administration.
\end{abstract}

Keywords: Hearing Loss, Age, Sex

\section{INTRODUCTION}

Hearing is one of the five senses that are used to communicate and interact, both between humans and with the surrounding environment. Hearing loss will reduce the ability to receive information and communicate through voice, so that it will complicate the implementation of work ${ }^{11}$. Hearing loss that is not corrected can lead to a decrease in quality of life, self isolation, decreased social activities and feelings not included, which can increase the prevalence of depressive symptoms ${ }^{2}$. According World Health Organization (WHO), there are an estimated 466 million (5\%) people in the world experience hearing loss, 432 million of which are adults and 34 million are children ${ }^{26}$.

Based on the results of the National Sense of Vision and Hearing Health Survey in 2012 conducted in 7 provinces in Indonesia, the prevalence of deafness was $0.4 \%$ and hearing loss was $16.8 \%$. The main causes of hearing loss are middle ear infections (3.1\%), presbycusis (2.6\%), ototoxic drug exposure $(0.3 \%)$, congenital $(0.1 \%)$, and noise exposure 12 . Besides hearing loss can also be caused by genetic factors, certain infectious diseases, and chronic ear infections ${ }^{27}$.

Commonly known drug classes that can cause hearing loss are aminoglycoside, diuretic, Nonsteroidal antiinflamatory drugs (NSAID), chemotherapy agents, and aminoglycoside class of ear drops ${ }^{23,13}$. According to the Indonesian Ministry of Health (KEMENKES RI), administration of drugs aminoglycosides (streptomycin and kanamycin) in patients with drug-resistant tuberculosis (TB RO) often cause hearing loss ${ }^{10}$. Drug-resistant tuberculosis is tuberculosis (TB) caused by Mycobacterium tuberculosis that has been immune to anti-tuberculosis drugs (OAT) ${ }^{9}$. 
OAT-resistant tuberculosis is basically a "man-made" phenomenon, as a result of inadequate TB patient treatment and transmission from OAT-resistant TB 7 patients. Treatment of RO TB patients consists of 2 (two) stages, namely the initial and advanced stages. In the initial stage, patients will receive a second line of at least 4 types of OAT which are still effective, namely levofloxacin, etionamide, cycloserine and kanamycin. In the advanced stage, all second line OAT used in the initial stage was continued except kanamycin ${ }^{9}$. The prevalence of hearing loss due to kanamycin in Surakarta Moewardi Hospital was $9.7 \%$ having hearing loss in the first month, and $37 \%$ in the sixth month ${ }^{19}$. This became more serious problems in patients with TB RO whose treatment is longer term ${ }^{9}$.

Kanamycin is an aminoglycoside drug which one of the side effects can cause hearing loss by damaging the cochlear outer hair cells, so that patients with TB RO who get aminoglycoside drug therapy are at risk of experiencing Sensorineural Hearing Loss (SNHL). The drug will initially affect the basal area of the cochlea. Furthermore, these exposures can cause damage to the apex. This can lead to a gradual SNHL, initially affecting only the high frequency, then extending to a lower frequency ${ }^{6,17}$. TB RO patients do not provide clinical symptoms if the hearing loss is at high frequency. However, this damage will continue so that eventually there will be wider damage and provide clinical symptoms. Hearing loss can be irreversible, bilateral and high frequency. Some patients experience worsening at low frequencies, often accompanied by tinnitus, and can occur deaf in total ${ }^{28,29}$.

Although the use of these aminoglycoside drugs cannot be stopped in TB RO patients, there is a strategy that can be done to reduce the level of hearing loss in these patients by conducting a monitoring of hearing function. Early detection of hearing loss due to ototoxic drugs provides an opportunity for doctors to evaluate the administration of therapy in minimizing or preventing hearing loss that requires rehabilitation ${ }^{4}$. If the patient has a disorder caused by kanamycin, then kanamycin can be replaced with capreomycin ${ }^{8}$. If there has been a significant hearing loss and have been detected, interventions can be done to help communication, by using hearing aids, cochlear implants, or other hearing aids, as well as conducting speech rehabilitation ${ }^{21}$.

Several factors that can increase the risk of one of the side effects of kanamycin in the form of hearing loss are age, sex, and period of drug administration ${ }^{29}$. Giving kanamycin at the age of 40 years more hearing loss than those aged less than 40 years ${ }^{14}$. Research conducted by Ratnawati, et al. found that female sex is more at risk of hearing loss than men ${ }^{19}$. Hearing loss due to kanamycin can occur after 3-4 days of administration or delayed in a matter of days, weeks, or months after treatment ${ }^{17}$. The longer the drug administration, the more the duration of exposure to toxic metabolites to our body and the risk of causing side effects will be greater ${ }^{16}$. On the basis of consideration of several factors that can increase the risk of one of the side effects of kanamycin, researchers are interested in knowing the relationship between age, sex on hearing loss and decreased hearing in TB RO patients during the administration of kanamycin in Abdul Wahab Sjahranie Hospital Samarinda.

\section{MATERIAL AND METHOD}

The design of this study was analytic with a cross sectional approach with retrospective data collection to determine the relationship between age, sex and hearing loss and hearing loss in patients with TB RO during the administration of kanamycin in Abdul Wahab Sjahranie Regional Hospital Samarinda 2017 to 2018 period. This study was conducted in the tulip poly hospital Abdul Wahab Sjahranie by looking at secondary data from the audiometry examination 
of TB RO patients. The variables studied in this study were in the form of age, sex and duration of drug administration at Abdul Wahab Sjahranie Regional Hospital Samarinda. The data obtained are tabulated according to frequency of distribution and percentage. Data processing is performed using Microsoft Word 2016 software, Microsoft Excel 2016 software, and Statistical Product and Service Solutions version 23. Data is presented in narrative, table and graphic form.

Table 1. General Characteristics

\begin{tabular}{lcc}
\hline \multicolumn{1}{c}{ General Characteristics } & N & \% \\
\hline Age group & & \\
$\quad>40$ years & 5 & 41,7 \\
$\quad \leq 40$ years & 7 & 58,3 \\
Sex & & \\
$\quad$ Male & 8 & 66,7 \\
$\quad$ Women & 4 & 33,3 \\
Hearing* & & \\
$\quad$ Normal & 5 & 41,7 \\
$\quad$ Hearing Loss & 7 & 58,3 \\
\hline
\end{tabular}

Note: (*): after completing kanamycin for 6 months

\section{RESULTS AND DISCUSSION}

This research is an analytical study, using secondary data in the form of medical record data of TB RO patients diagnosed at Abdul Wahab Sjahranie Regional Hospital 2017-2018. Based on medical record data obtained, there were 24 patients registered. Of the 24 people, 12 were excluded, namely, 6 patients were only registered for medical records, 4 patients had hearing loss from the start, and 2 patients could not be contacted for hearing re-examination after administration of kanamycin. In this study, 12 samples were found that met the inclusion criteria, based on the general characteristics of age, sex and hearing can be seen in table 1.

Based on Figure 1, the number of samples that had the most hearing loss at the age of 41-50 years was 3 people $(25.0 \%)$ (Figure 1). 


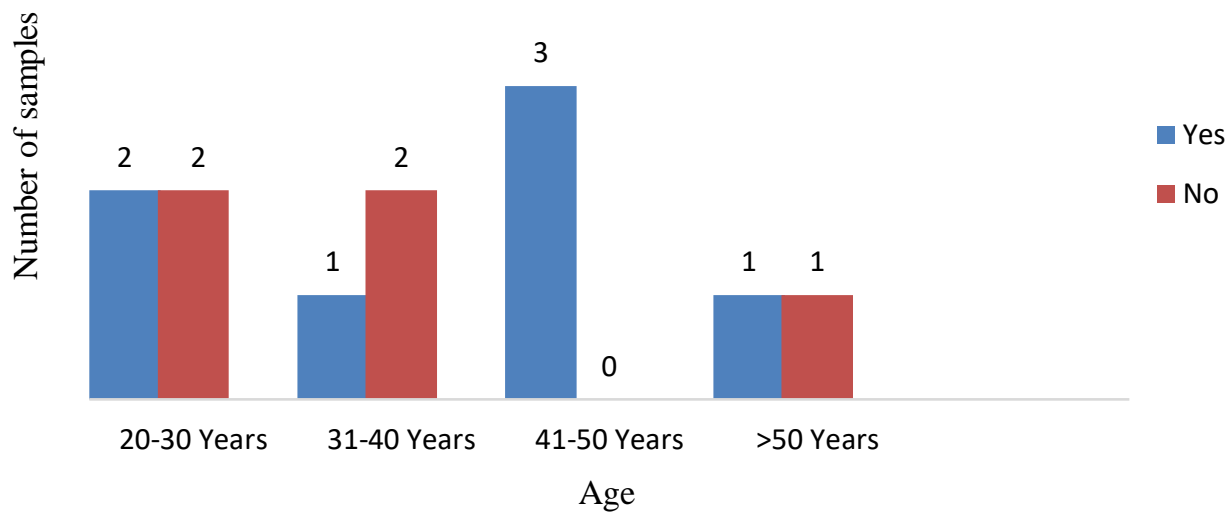

Figure 1. Frequency Distribution of Hearing Loss Based on Age of Patients Treated by Kanamycin

Table 2 shows the results of an analysis of 12 samples by showing a cross table between ages and hearing loss. Data were analyzed using Fisher's exact test because the expected count was less than 5.

Table 2. Cross Tabulation between Ages with Hearing Loss

\begin{tabular}{ccccccc}
\hline \multirow{2}{*}{ Usia } & \multicolumn{3}{c}{ Hearing Loss } & Total & \multirow{2}{*}{-value } \\
\cline { 2 - 5 } & Yes & $\%$ & No & $\%$ & & 0,293 \\
\hline 40 years & 4 & 33,3 & 1 & 8,3 & 5 & 0 \\
$\leq 40$ years & 3 & 25,0 & 4 & 33,3 & 7 & \\
Total & 7 & 58.3 & 5 & 41.7 & 12 & \\
\hline
\end{tabular}

Based on the results of research that has been done Fisher's test obtained $p$ value $=0.293(p>$ 0.05) so that it can be concluded that the administration of kanamycin there is no relationship between age and hearing loss. The results of this study are in line with research conducted by Wahyudin, Indrasworo, \& Wahyudiono, stating that in kanamycin there was no meaningful relationship between age and hearing loss ${ }^{24}$. The results of this study differ from studies conducted by Rakhmawati, Agustian, \& Wijana, stating that age is a factor that affects hearing loss, with increasing age affects the degeneration process so that elderly patients are more susceptible to hearing loss ${ }^{17}$.

In this study it was found that $\leq 40$ years of age can experience hearing loss. Mwansu, et al stated that age had no relationship with hearing loss, the difference in the effect of age with hearing loss can be influenced by differences in age categories and different observations.

Ratnawati, et al. reported that the higher the age the more the risk of hearing loss ${ }^{19}$. This occurs because the process of degeneration of sensory hair cells which causes a decrease in the 
number of hair cells in the cochlea decreases with age, older patients are more susceptible to ototoxicity $^{3}$. Other changes that occur related to age are disruption of the structure of the vascular stria (and the ciryal ligament), namely dislocation of the tectorial membrane from stereocilia, and loss of hair cells. Hearing loss due to loss of synaptic connections between the spiral ganglion and the audiori nerve. DNA mutations in the mitochondria can damage hearing function, and reduced blood flow can damage the oxidative phosphorylation of the mitochondria 5. Wargo, \& Edwards, states that old age is one of the risk factors for kidney dysfunction in the administration of kanamycin ${ }^{25}$.

Figure 2 shows the number of samples with hearing loss in men as many as 5 people (41.7\%), while women as much as 2 people (16.7\%) (Figure 2).

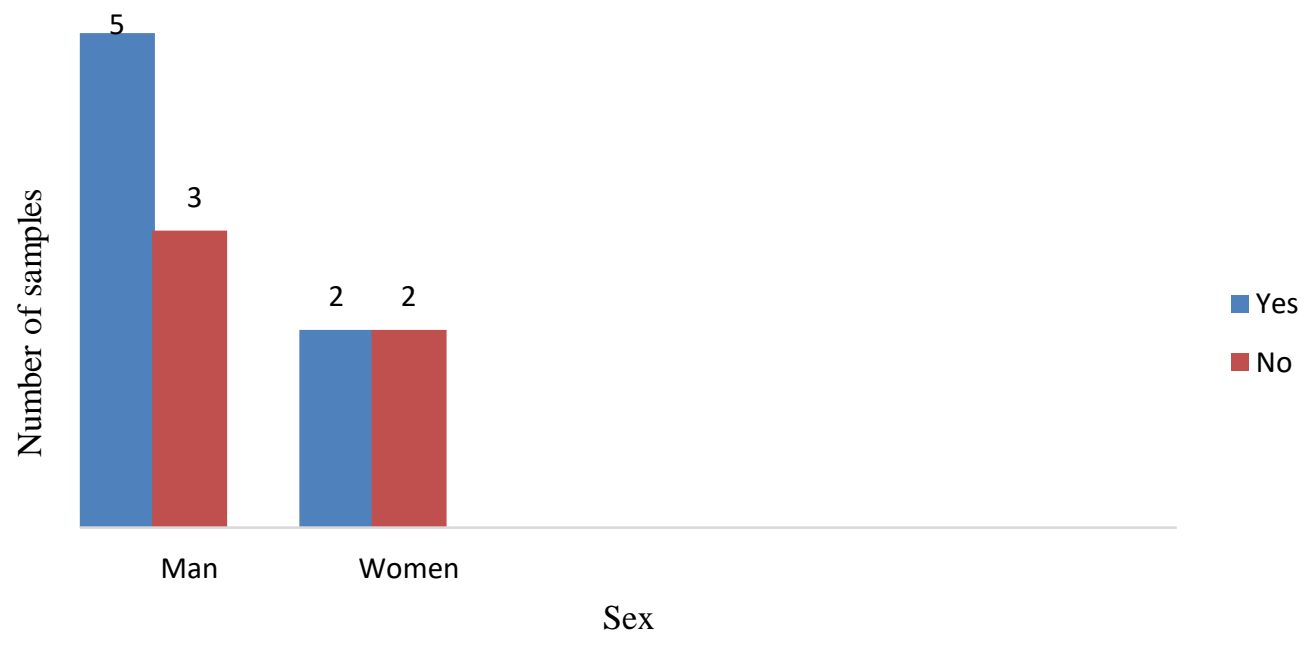

Figure 2. Frequency Distribution of Hearing Loss Based on the Gender of Patients Treated by Kanamycin

Table 3 shows the results of the analysis test of 12 samples by showing a cross table between sexes and hearing loss. Data were analyzed using Fisher's exact test because the expected count was less than 5 .

Table 3. Cross Tabulation Between Gender and Hearing Loss

\begin{tabular}{|c|c|c|c|c|c|c|}
\hline \multirow{2}{*}{ Sex } & \multicolumn{4}{|c|}{ Hearing Loss } & \multirow{2}{*}{ Total } & \multirow{2}{*}{$P$-value } \\
\hline & Yes & $\%$ & No & $\%$ & & \\
\hline Man & 5 & 41,7 & 3 & 25,0 & 8 & 1,000 \\
\hline Woman & 2 & 16,7 & 2 & 16,7 & 4 & \\
\hline Total & 7 & 58,3 & 5 & 41,7 & 12 & \\
\hline
\end{tabular}

Based on the results of research that has been done Fisher's test obtained $p=1,000(p>0.05)$ so that it can be concluded that the administration of kanamycin there is no relationship between 
sex with hearing loss. The results of this study are in line with research conducted by Ramma \& Ibekwe and Sharman, et al., Stating that there is no meaningful relationship between sex and hearing loss ${ }^{18,20}$. The results of this study differ from studies conducted by Ratnawati, et al. , states that there is a relationship between sex with hearing loss that is women are more at risk of hearing loss than men ${ }^{19}$.

The difference in these results can be caused by the number of sex samples obtained is different in each study, so the difference in the number of men and women in one study and the other is not significant. This difference still needs to be further investigated for possible genetic factors that play a role. The immune system can be one of the reasons that cause differences in hearing loss. Other causes such as smoking status are also a factor in hearing loss. The mechanism of hearing loss due to smoking occurs due to the direct ototoxic effects of nicotine and ischemic cochlea as a result of increased levels of carboxy hemoglobin, vasoconstriction, and increased blood viscosity ${ }^{15}$.

Before giving kanamycin all patients had normal hearing. After being given kanamycin therapy, 7 people $(58.3 \%$ ) had hearing loss (Figure 5.3), with different degrees of mild deaf 4 people $(33.3 \%)$, moderate deaf 1 person $(8.3 \%)$, moderate moderate deaf 1 person $(8.3 \%)$, and deaf very heavy 1 person $(8.3 \%)$.

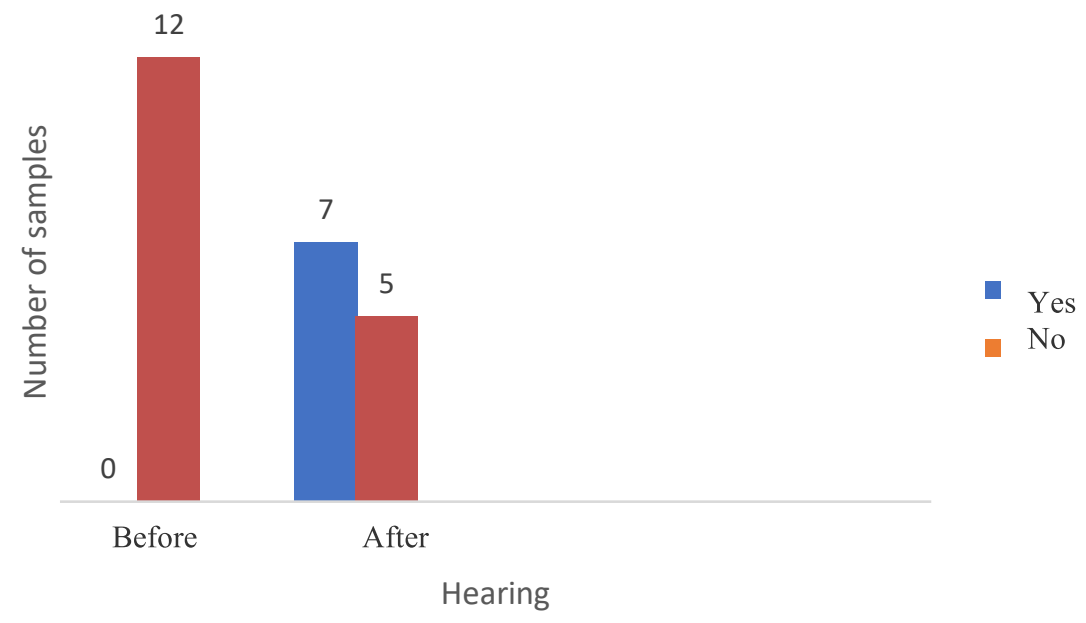

Figure 3. Distribution of Hearing Frequency Before and After Administration of Kanamycin

Table 4 shows the results of the analysis of 12 samples by showing a comparison table of audiometry before and after administration of kanamycin. Data normality test was analyzed, using the Shapiro-Wilk test, abnormal results were obtained $(\mathrm{p}<0.05)$ then it was performed using the Wilcoxon test.

Table 4. Audiometric comparison tables before and after administration of kanamycin 


\begin{tabular}{lccc}
\hline \multirow{2}{*}{$\begin{array}{c}\text { Audiogram } \\
\text { Examination }\end{array}$} & Normal & Audiogram & P-value \\
\cline { 2 - 3 } Before & 12 & 0 & 0,182 \\
After & 5 & 7 & \\
\hline
\end{tabular}

Based on the results of the study found 7 people have decreased hearing and 5 people with normal hearing. The results of this study the number of people who have hearing loss more than people with normal hearing, but when tested statistically using the Wilcoxon test obtained $\mathrm{p}=$ 0.182 ( $p>0.05$ ) so it can be concluded that there is no significant difference between hearing before and after kanamycin administration. The results of this study differ from studies conducted by Wahyudin, Indrasworo, \& Wahyudiono, which state that there are significant differences between hearing before and after administration of kanamycin ${ }^{24}$.

The difference in results from this study with research conducted by Wahyudin, Indrasworo, \& Wahyudiono can be caused by the onset of hearing loss. As with all aminoglycosides, hearing loss can occur at the beginning of therapy or several months after the completion of drug therapy 24. In a study conducted at Abdul Wahab Hospital Sjahranie Samarinda, hearing re-examination was conducted after 1 year of kanamycin administration there were differences in hearing before and after administration of kanamycin but there is no relationship between the duration of administration of kanamycin with the occurrence of hearing loss. The results of the study conducted by Oliviera found that the longer the duration of drug administration, the longer exposure to toxic metabolites to the body and the risk of causing side effects will be greater ${ }^{16}$. Rakhmawati, Agustian, \& Wijana stated initial exposure to ototoxic drugs can usually affect the basal area of the cochlea. Further exposure causes the spread of damage to the apex ${ }^{17}$. According to Huth, Ricci, \& Cheng damage to the cochlea that occurs in the outer hair cells causes hearing loss and affects the process of auto-acoustic emission. Other factors that can increase the risk of hearing loss are other effects of aminoglycosides that are nephrotoxic, because they induce proximal tubular necrosis ranging from focal to diffuse lesions. metabolic acidosis, and disorders of calcium metabolism that can affect the cationic gradient in the cochlea and can interfere with hearing function ${ }^{22}$.

\section{CONCLUSION}

The conclusion of this study is that age, gender are not associated with hearing loss and there is no hearing loss in patients with TB RO in Abdul Wahab Sjahranie Hospital Samarinda. The need for hearing monitoring to determine the degree of hearing during the administration of kanamycin in old age to prevent the risk of hearing loss and further research can be done to find out other factors that can cause differences in hearing based on sex, for example consuming cigarettes and kidney failure.

The weakness of this study was the lack of completeness of the medical record, because there were some patients who did not undergo OAT treatment. Some patients who have 
undergone OAT treatment cannot be contacted for a repeat hearing examination after the completion of OAT treatment at an early stage, one of which is using kanamycin. This makes the number of patients obtained is small and the sample that meets the inclusion criteria is small.

\section{REFERENCES}

1. Aditama, T.Y. Tuberkulosis: Pedoman Diagnosis dan Penatalaksanaan di Indonesia. Jakarta: PERPARI, (2006).

2. Arlinger, S. Negative Consequences of Uncorrected Hearing Loss-A Review. International Journal of Audiology. 42(2), 17-20 (2003).

3. Chambers, H. F. 2007. Senyawa antimikroba aminoglikosida. In H. Joel, L. Lee (Eds.). Dasar farmakologi terapi (Vol. 2). Jakarta: EGC, pp. 1195-1204

4. Direktorat Jenderal Pengendalian Penyakit dan Penyehatan Lingkungan. 2011. Pengendalian TB resistan Obat. Sub Direktorat Tuberkulosis. Jakarta: DepKes RI.

5. Huang, Q., \& Tang, J. Age-related hearing loss or presbycusis. European Archives of Otorhino-laryngology. 267(8), 1179-1191 (2010).

6. Huth, M. E., Ricci, A. J., \& Cheng, A. G. Mechanisms of aminoglycoside ototoxicity and targets of hair cell protection. International Journal of Otolaryngology. 1-11 (2011).

7. Kementrian Kesehatan Republik Indonesia (KEMENKES RI). 2014. Pedoman Nasional Pengendalian Tuberkulosis. Jakarta: KEMENKES RI.

8. KEMENKES RI. 2016. Penanggulangan Tuberkulosis. Jakarta: KEMENKES RI.

9. KEMENKES RI. 2017. Pengobatan Pasien Tuberkulosis. Jakarta: KEMENKES RI.

10. KEMENKES RI. 2018. Pendengaran Sehat Untuk Hidup Bahagia. Jakarta: KEMENKES RI.

11. Kusman, A., Sulistiyana, C. S., \& Hendratno, S. Hubungan Antara Kebisingan Dengan Gangguan Pendengaran Pada Pekerja Penggilingan Beras. Tunas Medika Jurnal Kedokteran \& Kesehatan. 2(1) (2015).

12. Liang, K., Mona, M., \& Tumbel, R. E. C. Survei Kesehatan Telinga Masyarakat di Desa Tinoor 2. e-CliniC, 6(1) (2018).

13. Miller, Monica L., Blakenship, Crystal. Ototoxicity. In Tisdale, J., Miller, D., Drug-induced disease (2 ${ }^{\text {nd }}$ Ed.). America: ASHP. 1049-1054 (2010).

14. Mwansasu, C. S., Siziya, S., \& Mpondo, B. C. T. Hearing Loss among Multi-Drug Resistant Tuberculosis patients on Kanamycin in Ndola Teaching Hospital, Zambia: Study of ototoxicity and practice. Health Press Zambia Bull. 1(4), 72-78 (2017).

15. Nair, P. G., Jestina, J., Unnikrishnan, H., \& Chandrahasan, H. Effects of Cigarette Smoking on Auditory Function. Research in Otolaryngology. 17(2), 9-15 (2016).

16. Oliviera, I. Pola Kejadian Penyakit Komorbid dan Efek Samping OAT pada Pasien Tuberkulosis Di RSUP DR. Karyadi. Jurnal Kedokteran Diponegoro. 5(4), 1081-1091 (2016).

17. Rakhmawati, L., Agustian, R. A., \& Wijana. Peluang Kejadian Ototoksisitas pada Penggunaan Kanamisin dalam Pengobatan Tuberkulosis Tuberkulosis resistan Obat Ganda Selama Satu Bulan. Majalah Kedokteran Bandung-E-Journal Faculty of Medicine Universitas Padjadjaran. 47(4), 224-230 2015.

18. Ramma, L., \& Ibekwe, T. S. Cochleo-vestibular clinical findings among drug resistant tuberculosis patients on therapy-a pilot study. International archives of medicine. 5(3), 1-5 (2012). 
19. Ratnawati, M., Reviono, Putranto, W., Sutanto, Y. S., \& Harsini. Pengaruh Faktor Risiko Terhadap Waktu Timbulnya Efek Samping Kanamisin Pada TUberkulosis resistan Obat. Majalah Kedokteran Bandung. 50(2), 86-92 (2018).

20. Sharman, V., Bhagar, S., Verma, B., Singh, R., \& Singh, S. Audiological evaluation of patients taking kanamycin for multidrug resistant tuberculosis. Iranian Journal Of Otorhinolaryngology. 28(3), 203-8 (2016).

21. Seddon, J. A., Godfrey-Faussett, P., Jacobs. K., Ebrahim, A., Hesseling, A. C., \& Schaaf, H. $\mathrm{S}$. Hearing loss in patients on treatment for drug resistant tuberculosis. The European Respiratory Journal. 40(5), 1277-1286 (2012).

22. Silbernagi, S. \& Lang, F. 2000. Color atlas of pathophysiology. USA : Thieme, pp. 110-1.

23. Soetirto, I., Bashirudin, J. \& Bramantyo, B. 2012. Gangguan pendengaran akibat obat ototoksik. In E. A. Soepardi, N. Iskandar, J. Bashiruddin, R. D. Restuti (Eds.). Buku Ajar Ilmu Kesehatan Telinga Hidung Tenggorok Kepala \& Leher $\left(7^{\text {th }}\right.$ Ed.). Jakarta: FKUI.

24. Wahyudin, W. Indrasworo, D., \& Wahyudiono, A. D. Hubungan pemberian Kanamisin dengan kejadian ototoksik pada penderita tuberculosis multi drug resistance. Oto Rhino Laryngologica Indonesia. 48(2), 121-128 (2018).

25. Wargo, K. A. \& Edwards, J. D. Aminoglycoside induced nephrotoxicity. Journal Pharmacy Practie. 27(6), 573-7 (2014).

26. WHO. 2018. Deafness and Hearing Loss. Geneva: WHO.

27. WHO. 2017. Deaffness and hearing loss. Geneva: WHO

28. WHO. 2011. Guidelines for management of drug resistant tuberculosis. Geneva: WHO.

29. Yulianti \& Mahdiani, S. Gangguan Pendengaran Penderita Tuberkulosis Multidrug Resistant. Indonesian Journal of Otorhinolaryngology - Head and Surgery. 45(2), 83-89 (2015). 